\title{
High Metal Contents in Coffee Plant Organs Developed in Tubets with Different Proportions of Biosolid Composts and Carbonized Rice Hulls
}

\author{
Elias Franco*, Edison Miglioranza and Ésio de Pádua Fonseca \\ Departamento de Agronomia; Centro de Ciências Agrárias; Universidade Estadual de Londrina; \\ ciafranco@bol.com.br; emiglior@uel.br; esiof@uel.com.br; C.P. 6001; 86051-990; Londrina - PR - Brazil
}

\begin{abstract}
The objective of this study was to analyze the effect of biosolid composts $(B C)$ and carbonized rice hull $(R H)$ on the production of Coffea arabica L. cv Catuai Vermelho seedlings (IAC H 2077-2-5-99) grown in tubets. A totally randomized experimental design with five treatments and four replications was conducted in a nursery, to evaluate $\mathrm{Co}, \mathrm{Ni}, \mathrm{Cr}, \mathrm{Pb}, \mathrm{Cu}, \mathrm{Mn}$ and $\mathrm{Zn}$ contents in roots, stems and leaves. Higher contents of $\mathrm{Cr}, \mathrm{Co}, \mathrm{Ni}, \mathrm{Pb}, \mathrm{Cu}$ and $\mathrm{Zn}$ were found in roots, while leaves carried the highest content of Mn. Zn in leaves went from average to high in plants developed in BC. In plants developed in RH. Mn content was about four times higher than the adequate concentration. $\mathrm{Ni}, \mathrm{Co}, \mathrm{Cr}, \mathrm{Pb}$ and $\mathrm{Cu}$ contents found in leaves were considered normal, according to international standards. The best treatment for coffee seedling nutrition was $50 \% \mathrm{RH}+50 \% \mathrm{BC}$.
\end{abstract}

Key words: Coffea arabica L., substrate, sewage sludge, coffee nutrition, coffee seedling

\section{INTRODUCTION}

The greatest problem in urban sanitation is the final destination of sewage sludge residues. So far, many stations have kept these residues near their facilities, posing considerable risks to the environment (Lara, 1999; Fernandes et al.).

The Paraná Sanitation Company - SANEPAR defines sewage sludge as solid residues created by treatment systems of residual water. However, according to WEF (Water Environmental Federation) regulations, these residues should be classified as biosolids, provided they are predominantly organic and beneficial (Andreoli and Pegorini, 1998).

Due to their high nutrient content and performance as a conditioner of physical, chemical and biological properties of the soil, the use of biosolids as organic fertilizers has been recommended as an alternative for the final destination of these residues.

According to Miyazawa et al. (1998), high contents of $\mathrm{N}, \mathrm{P}, \mathrm{K}, \mathrm{Ca}, \mathrm{Mg}$ and $\mathrm{S}$ can be found in biosolids. They reduce soil density, favor the formation of aggregates (Jorge et al., 1991) and increase overall porosity (Pagliai et al., 1981 and Ortega et al., 1981). Nevertheless, the presence of pathogenic microorganisms (such as Escherichia coli and Salmonella), toxic organic composts (pesticides, fungicides and others) and heavy metals such as $\mathrm{Cd}, \mathrm{Hg}, \mathrm{Pb}, \mathrm{Cr}$, and $\mathrm{Cu}$ are the main restrictions to the use of biosolids in agriculture (Tiller, 1989; Tsadilas et al., 1995). When composting is controlled, biosolids can be

\footnotetext{
* Author for correspondence
} 
more advantageous and consequently have different applications (Soccol et al., 1997). Thermophilic microorganism populations occur throughout the composting process, which keeps the environment temperature high for many days $\left(55-65^{\circ} \mathrm{C}\right), \quad$ killing most pathogenic microorganisms. According to Fernandes et al., (1996), the helminth eggs probability was reduced to $100 \%$ during the composting process. In corn cultures, the application of biosolid composts led to an increase in dry matter production in shoot height (Berton et al., 1989; Amaral et al. 1996), as well as in productivity (Biscaia and Miranda, 1996).

According to Wallace and Wallace (1994), compost products based on sewage sludge used in landscape gardening have been commercialized in the Los Angeles area (USA). Plants have shown toxicity symptoms due to the presence of $\mathrm{Zn}$ and, in some cases, an increase in $\mathrm{Cd}, \mathrm{Cu}, \mathrm{Pb}$ and $\mathrm{Ni}$ contents, in are as which have been using this kind of product for more than 40 years. Carbonized rice hulls are considered good substrates for seedlings production through seeds and stake rooting. They are composed of a light, porous material that allows good airing and draining, keeps a constant volume and is free from weeds, nematodes and pathogens. Due to the carbonizing process (Souza, 1993) there's no need to treat them chemically. Rice hulls can be used pure or mixed with other substrates for the formation of seedlings of different kinds of plants such as forest, fruit, agricultural and ornamental plants. Carbonized rice hulls that are properly fertilized can be used in the production of coffee plant seedlings.

The production of seedlings is among the best alternatives for biosolid use in agriculture. In this type of production, the biosolid can be used alone (not mixed with other materials) and, depending on the concentration of heavy metals there can be a reduction in the growth and development of seedlings as well as in the phytotoxicity symptoms.

This study was developed to evaluate heavy metal contents in the roots, stems and leaves of Coffea arabica $L$ 'Catuaí Vermelho IAC-99' seedlings developed in tubets filled with different proportions of bio-solid compost and carbonized rice hulls, using a slow-liberation fertilizer.

\section{MATERIALS AND METHODS}

The experiment was conducted in a nursery located in Londrina, PR, $23^{\circ} 23^{\prime}$ south (latitude) and $51^{\circ} 11^{\prime}$ west (longitude) of Greenwich, with the average height of $566 \mathrm{~m}$., in a Cfa type of climate, according to Köppen. The radiant flux density was attenuated by a black polypropylene screen with a 50\% retention capacity. In the suspended irrigation system, micro-sprinklers with an outflow of 75 L.h ${ }^{-1}$ were used. During the experiment, seedlings were irrigated three times a day (at $8.30 \mathrm{am} ., 12.30 \mathrm{pm}$. and $5.30 \mathrm{pm}$.) for 15 minutes.

Basic Coffea arabica L. cv Catuaí Vermelho IAC-99 seedlings were sown in a seedbed with washed thick sand. After the plantules reached the 'matchstick' stage, on October 26 1999, they were transplanted to black, rigid, $0.14 \mathrm{~m}$ high polypropylene tubets measuring $0.035 \mathrm{~m}$ (internal diameter) in the upper opening, $0.015 \mathrm{~m}$ (diameter) in the lower opening, weighing $120 \mathrm{ml}$, and with six longitudinal strias inside.

Substrates consisted of carbonized rice hull proportions (RH) and bio-solid composts (BC) provided by the Paraná Sanitation Company SANEPAR. Tubets were filled manually sixty days before transplantation, and alternately distributed on a screen net (with $0.04 \mathrm{~m}$ and a 14 $\mathrm{mm}$ wire) fixed on iron tables $1.30 \mathrm{~m}$ wide, $4.5 \mathrm{~m}$ long and $0.80 \mathrm{~m}$ high. The slow liberation fertilizer known as Osmocote ${ }^{\circledR}$ was added to all treatments, in an $8.0 \quad \mathrm{~kg} . \mathrm{m}^{-3}$ substrate dose. According to the manufacturer, this fertilizer contains $15 \% \mathrm{~N}$ (7\% ammoniac and $8 \%$ nitric); $9 \% \mathrm{P}_{2} \mathrm{O}_{5} ; 12 \% \quad \mathrm{~K}_{2} \mathrm{O} ; 3.5 \% \mathrm{Ca} ; 1 \% \mathrm{Mg} ; 2.3 \% \mathrm{~S}$; $0.02 \% \mathrm{~B} ; 0.05 \% \mathrm{Cu} ; 0.45 \% \mathrm{Fe} ; 0.06 \% \mathrm{Mn} ; 0.02 \%$ Mo and $0.05 \% \mathrm{Zn}$.

For the chemical analysis, the carbonized rice hull samples and biosolid composts were dried in a greenhouse with forced air circulation at $65^{\circ} \mathrm{C}$ until reaching constant weight. Nitrogen analysis was done through sulfuric digestion $\left(\mathrm{H}_{2} \mathrm{SO}_{4}+\right.$ $\mathrm{CuSO}_{4}+\mathrm{K}_{2} \mathrm{SO}_{4}$ ). The carbon content was measured by the Walkley-Black method and the $\mathrm{pH}$ was determined by calcium chloride $0.1 \mathrm{M}$. For the extraction of $\mathrm{P}, \mathrm{K}, \mathrm{Ca}, \mathrm{Mg}, \mathrm{S}, \mathrm{Na}, \mathrm{B}, \mathrm{Cu}, \mathrm{Zn}$, $\mathrm{Fe}, \mathrm{Mn}, \mathrm{Co}, \mathrm{Ni}, \mathrm{Cr}, \mathrm{Pb}$ and $\mathrm{Cd}, \mathrm{a} 1 \mathrm{~N}\left(\mathrm{HNO}_{3}+\right.$ $\left.\mathrm{HClO}_{4}\right)$ solution was used. The heavy metals $\mathrm{Co}$, $\mathrm{Ni}, \mathrm{Cr}, \mathrm{Pb}, \mathrm{Cd}, \mathrm{Cu}, \mathrm{Mn}$ and $\mathrm{Zn}$ were determined by atomic emission spectrometry with induced plasma, using a Thermo Jarrel-ash ICAP 61E 
(ICP-EAS) model spectrometer.

A total randomized experimental design with five treatments and four replications was used. Each plot was composed of six plants in rows and six in columns, with a total of 36 plants. Treatments were obtained from the following mixtures in volume $(\mathrm{v} / \mathrm{v})$ :

$\mathrm{T} 1=100 \%$ carbonized rice hull $(\mathrm{RH})$ and $0 \%$ bio-solid compost (BC);

$\mathrm{T} 2=75 \%$ carbonized rice hull $(\mathrm{RH})$ and $25 \%$ bio-solid compost (BC);

$\mathrm{T} 3=50 \%$ carbonized rice hull $(\mathrm{RH})$ and $50 \%$ bio-solid compost (BC);

$\mathrm{T} 4=25 \%$ carbonized rice hull $(\mathrm{RH})$ and $75 \%$ bio-solid compost (BC);

$\mathrm{T} 5=0 \%$ carbonized rice hull $(\mathrm{RH})$ and $100 \%$ bio-solid compost (BC).

Four plants were taken from the center of each plot, 180 days after transplantation. Root, stem and leaves were identified and placed in porous paper bags for drying. Dried matter was obtained in a greenhouse with forced air circulation at $75^{\circ} \mathrm{C}$ where the plant parts remained until they reached constant weight.

The determination of $\mathrm{Co}, \mathrm{Ni}, \mathrm{Cr}, \mathrm{Pb}, \mathrm{Cd}, \mathrm{Mn}$ and $\mathrm{Zn}$ contents in each part of the plantules was carried out through atomic emission spectrometry with induced plasma, with a Thermo Jarrel-ash ICAP 61E (ICP-EAS) model spectrometer.

Data were submitted to an analysis of variance and the means were compared by the Genetic and Statistical Analysis System (GSAS), version 5.0 (Euclides, 1983).

\section{RESULTS AND DISCUSSION}

Table 1 shows nutrient and heavy metal contents in two substrates used in the experiment. Table 2 shows heavy metal contents in roots, stems and leaves from cultivated coffee plant seedlings, in carbonized rice hulls, in bio-solid composts (alone and mixed).

Table 1 - Macro and micro nutrient contents in carbonized rice hulls and bio-solid compost UEL, Londrina, PR 2001.

\begin{tabular}{|c|c|c|c|c|c|c|c|c|c|c|c|c|c|c|c|c|c|c|c|c|}
\hline Source & $\mathbf{N}$ & $\ldots$ & $\begin{array}{r}\mathbf{K} \\
\mathbf{g}\end{array}$ & $\begin{array}{r}\mathrm{Ca} \\
\mathrm{kg}^{-1}\end{array}$ & Mg & $\begin{array}{c}\mathrm{S}- \\
\mathrm{SO}_{4}\end{array}$ & C & $\mathrm{Na}$ & B & $\mathrm{Cu}$ & $\mathbf{Z n}$ & $\mathbf{F e}$ & $\begin{array}{c}\text { Mn } \\
\text { mg.kg-1 }\end{array}$ & Co & $\mathbf{N i}$ & $\mathrm{Cr}$ & $\mathbf{P b}$ & Cd & pH & $\begin{array}{c}\text { Hum } \\
\text { idity } \\
\text { at } \\
65^{\circ} \mathrm{C}\end{array}$ \\
\hline $\begin{array}{l}\text { Carbonized } \\
\text { rice hull } \\
\text { Bio-solid }\end{array}$ & 7.4 & 2.05 & 7.5 & 2.05 & 1.82 & 1.18 & 175.8 & 100 & 9 & 53 & 86 & 12.779 & 705 & $X^{1}$ & $\mathrm{X}$ & $X$ & $\mathrm{X}$ & $\mathrm{X}$ & 6.5 & 5.8 \\
\hline compost & 28.7 & 5.60 & 1.7 & 24.8 & 2.6 & 4.3 & 338.7 & 250 & 16 & 517 & 1.560 & 22.235 & 503 & 13 & 63 & 108 & 198 & 0 & 5.5 & 10.4 \\
\hline
\end{tabular}

\section{Chrome}

Chrome was most accumulated in the root $(8.40$ to $14.31 \mathrm{mg} \cdot \mathrm{kg}^{-1}$ dry matter (DM), and the stem showed the lowest content for this element (6.98 to

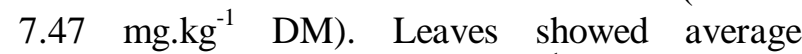
contents (7.89 to 10.97 mg.kg ${ }^{-1}$ DM). Coffee seedlings grown on pure or mixed with carbonized rice hull biosolid composts (BC) presented significantly higher $\mathrm{Cr}$ content in the roots when compared to those grown on pure carbonized hull (RH). However, no difference was found for stems. Cr content was significantly higher in seedlings grown on $25 \%$ of $\mathrm{RH}+75 \%$ of $\mathrm{BC}$ than in those grown on $100 \%$ of RH and $100 \%$ of BC. The use of biosolids from Treatment Stations in Paraná in bean plant plantations resulted in $\mathrm{Cr}$ contents similar to those of the witness. (Miyazawa et al., 1998). According to Dias et al.
(1996), when the BC dose in the graniferous sorghum crop was increased, there was a linear growth in the $\mathrm{Cr}$ availability in the soil. To Bidwell and Dowdy (1987), the Cr concentrations in the culm and corn grains oscillated according to the year of cultivation, with no correlation with the sludge used.

The $\mathrm{Cr}$ content found in the biosolid compost analysis was 108 mg. $\mathrm{kg}^{-1}$ dry matter, which is much lower than the $750 \mathrm{mg} \cdot \mathrm{kg}^{-1}$ accepted by the European Economic Community for the incorporation of the material to the soil (Fernandes et al., 1993). The $\mathrm{Cr}$ concentration in biosolid has varied between 8 and $40,600 \mathrm{mg} \cdot \mathrm{kg}^{-1}$ dry matter and these considerable variations depend on the economical activities carried out in each sampled region (Bidwell and Dowdy, 1987). 
Table 2 - Means of Chrome, Cobalt, Nickel, Lead, Manganese, Copper and Zinc in leaves, stems and roots of coffee seedlings developed in carbonized rice hulls (RH) and in biosolid compost (BC) and its mixtures.

\begin{tabular}{|c|c|c|c|c|c|c|c|c|}
\hline & Treatments & $\mathrm{Cr}$ & Co & $\mathbf{N i}$ & $\begin{array}{r}\mathbf{P b} \\
\text { mg.kg }\end{array}$ & Mn & $\mathbf{C u}$ & Zn \\
\hline \multirow[t]{5}{*}{ Roots } & RH(100\%) & $8.40 \mathrm{~B}$ & $2.40 \mathrm{~A}$ & $3.77 \mathrm{~B}$ & $3.38 \mathrm{~B}$ & $179.01 \mathrm{~A}$ & $9.57 \mathrm{C}$ & $107.82 \mathrm{~B}$ \\
\hline & $\begin{array}{l}\mathrm{RH}(75 \%)+ \\
\mathrm{BC}(25 \%)\end{array}$ & $11.60 \mathrm{~A}$ & $2.71 \mathrm{~A}$ & $12.48 \mathrm{~A}$ & $12.47 \mathrm{~A}$ & $99.66 \mathrm{~B}$ & $37.48 \mathrm{~B}$ & $1398.89 \mathrm{~A}$ \\
\hline & $\begin{array}{l}\mathrm{RH}(50 \%)+ \\
\mathrm{BC}(50 \%)\end{array}$ & $12.79 \mathrm{~A}$ & $2.94 \mathrm{~A}$ & $12.69 \mathrm{~A}$ & $14.40 \mathrm{~A}$ & $88.65 \mathrm{~B}$ & $41.48 \mathrm{~B}$ & $1302.00 \mathrm{~A}$ \\
\hline & $\begin{array}{l}\mathrm{RH}(25 \%)+ \\
\mathrm{BC}(75 \%)\end{array}$ & $13.29 \mathrm{~A}$ & $2.88 \mathrm{~A}$ & $11.80 \mathrm{~A}$ & $17.00 \mathrm{~A}$ & $76.39 \mathrm{~B}$ & $46.99 \mathrm{AB}$ & $1358.59 \mathrm{~A}$ \\
\hline & $\mathrm{BC}(100 \%)$ & $14.31 \mathrm{~A}$ & $3.44 \mathrm{~A}$ & $12.65 \mathrm{~A}$ & $18.85 \mathrm{~A}$ & 89.72 B & $59.19 \mathrm{~A}$ & $1474.65 \mathrm{~A}$ \\
\hline \multirow[t]{5}{*}{ Stems } & RH(100\%) & $6.98 \mathrm{~A}$ & $0.23 \mathrm{~B}$ & $3.87 \mathrm{~B}$ & $2.95 \mathrm{~A}$ & $132.75 \mathrm{~A}$ & $6.07 \mathrm{~B}$ & $18.77 \mathrm{~B}$ \\
\hline & $\begin{array}{l}\mathrm{RH}(75 \%)+ \\
\mathrm{BC}(25 \%)\end{array}$ & $6.98 \mathrm{~A}$ & $0.26 \mathrm{~B}$ & $5.38 \mathrm{~A}$ & $1.94 \mathrm{~A}$ & $74.71 \mathrm{~B}$ & $8.77 \mathrm{AB}$ & $99.47 \mathrm{~A}$ \\
\hline & $\begin{array}{l}\mathrm{RH}(50 \%)+ \\
\mathrm{BC}(50 \%)\end{array}$ & $7.32 \mathrm{~A}$ & $0.41 \mathrm{AB}$ & $6.10 \mathrm{~A}$ & $4.71 \mathrm{~A}$ & $63.59 \mathrm{~B}$ & $9.85 \mathrm{~A}$ & $79.91 \mathrm{~A}$ \\
\hline & $\begin{array}{l}\mathrm{RH}(25 \%)+ \\
\mathrm{BC}(75 \%)\end{array}$ & $7.47 \mathrm{~A}$ & $0.44 \mathrm{AB}$ & $5.43 \mathrm{~A}$ & $3.60 \mathrm{~A}$ & $58.13 \mathrm{~B}$ & $10.70 \mathrm{~A}$ & $82.32 \mathrm{~A}$ \\
\hline & $\mathrm{BC}(100 \%)$ & $7.31 \mathrm{~A}$ & $0.52 \mathrm{~A}$ & $5.11 \mathrm{AB}$ & $3.04 \mathrm{~A}$ & $56.35 \mathrm{~B}$ & $11.07 \mathrm{~A}$ & $88.00 \mathrm{~A}$ \\
\hline \multirow[t]{5}{*}{ Leaves } & $\mathrm{RH}(100 \%)$ & $7.89 \mathrm{C}$ & $0.81 \mathrm{~A}$ & $3.65 \mathrm{~B}$ & $6.19 \mathrm{~A}$ & $477.76 \mathrm{~A}$ & $8.60 \mathrm{~A}$ & $12.83 \mathrm{~A}$ \\
\hline & $\begin{array}{l}\mathrm{RH}(75 \%)+ \\
\mathrm{BC}(25 \%)\end{array}$ & $9.15 \mathrm{ABC}$ & $0.93 \mathrm{~A}$ & $5.33 \mathrm{~A}$ & $6.89 \mathrm{~A}$ & $175.86 \mathrm{~B}$ & $7.73 \mathrm{~A}$ & $17.81 \mathrm{~A}$ \\
\hline & $\begin{array}{l}\mathrm{RH}(50 \%)+ \\
\mathrm{BC}(50 \%)\end{array}$ & $10.26 \mathrm{AB}$ & $1.21 \mathrm{~A}$ & $6.24 \mathrm{~A}$ & $9.10 \mathrm{~A}$ & $152.00 \mathrm{~B}$ & $6.85 \mathrm{~A}$ & $15.48 \mathrm{~A}$ \\
\hline & $\begin{array}{l}\mathrm{RH}(25 \%)+ \\
\mathrm{BC}(75 \%)\end{array}$ & $10.97 \mathrm{~A}$ & $1.23 \mathrm{~A}$ & $5.19 \mathrm{~A}$ & $8.94 \mathrm{~A}$ & $113.07 \mathrm{~B}$ & $6.79 \mathrm{~A}$ & $15.46 \mathrm{~A}$ \\
\hline & $\mathrm{BC}(100 \%)$ & $8.86 \mathrm{BC}$ & $0.76 \mathrm{~A}$ & $4.85 \mathrm{AB}$ & $7.85 \mathrm{~A}$ & 116.32 B & $9.72 \mathrm{~A}$ & $22.05 \mathrm{~A}$ \\
\hline
\end{tabular}

Means followed by the same letters in the seedling part column do not differ among themselves by the Tukey test at the 5\% of probability

Internationally speaking, the $\mathrm{Cr}$ content in soils varies from 18.7 to $285 \mathrm{mg} \cdot \mathrm{kg}^{-1}$ (Souza et al., 1996). The critical levels of $\mathrm{Cr}$ vary from 75 to 100 mg.kg ${ }^{-1}$ (Kabata Pendias and Pendias, 1984). According to these criteria, the Eutrophic Structured Red Soils (Souza et al., 1996) present higher $\mathrm{Cr}$ contents than these critical levels and those found in the chemical analysis of the biosolid compost used as substrate in this experiment.

\section{Cobalt}

The highest Co content was found in the roots (2.40 to $3.44 \mathrm{mg} \cdot \mathrm{kg}^{-1} \mathrm{DM}$ ), while the lowest content was found in the stems $(0.23$ to 0.52 mg. $\left.\mathrm{kg}^{-1} \mathrm{DM}\right)$. Leaves presented intermediate levels of Co contents ( 0.81 to $1.23 \mathrm{mg} \cdot \mathrm{kg}^{-1} \mathrm{DM}$ ). Miyazawa et al. (1998) found lower levels Co contents - from one to $4.56 \mathrm{mg} \cdot \mathrm{kg}^{-1}$ dry matter - while working with different kinds of biosolids in bean plant tissues. BC mixed with $\mathrm{RH}$ produced an increase in Co content in the stem. Seedlings grown on pure $\mathrm{BC}$ presented significantly higher Co content in the stem than those grown under $\mathrm{RH}$ treatments. Content differences were not significant for roots and leaves.

Co content found in the biosolid compost sample used in this experiment was $13 \mathrm{mg} \cdot \mathrm{kg}^{-1}$ dry matter. This is much lower than the $50 \mathrm{mg} \cdot \mathrm{kg}^{-1}$ dry matter, and the $100 \mathrm{mg} \cdot \mathrm{kg}^{-1}$ dry matter recommended by Switzerland for the incorporation of the material to the soil (Fernandes et al., 1993).

According to international criteria, the Co content in soils varies from 1.0 to $70 \mathrm{mg} \cdot \mathrm{kg}^{-1}$ dry matter (Souza et al., 1996), and Co critical levels are from 25 to 50 mg. $\mathrm{kg}^{-1}$ (Kabata-Pendias and Pendias, 1984). Eutrophic Structured Red Soils present 
higher Co contents than the critical levels established by these criteria (Souza et al., 1996), as well as the contents found in the chemical analysis of the biosolid compost used as substrate in this experiment.

\section{Nickel}

Highest Ni content was found in the root (3.77 to $\left.12.69 \mathrm{mg} \cdot \mathrm{kg}^{-1} \mathrm{DM}\right)$. Content levels were similar in the stem and leaves, and varied from 3.65 to 6.24 mg. $\mathrm{kg}^{-1}$ DM. Arteaga (1996) also found higher Ni contents in the wheat root than in the shoot height. Miyazawa et al. (1998) found Ni contents in bean plant shoot heights, varying from less than two to $4.98 \mathrm{mg} . \mathrm{kg}$, while working with different kinds of biosolids in bean plant shoot heights. Pure or mixed $\mathrm{BC}$ produced a significant increase in $\mathrm{Ni}$ content in the roots. The stem as well as the roots of the seedlings grown on pure $\mathrm{RH}$ presented lower $\mathrm{Ni}$ content, which differed significantly from the content found in seedlings grown on the $\mathrm{RH}$ with BC mixture. The use of biosolids from Treatment Stations in Paraná in bean plantations resulted in $\mathrm{Ni}$ contents similar to those in the witness (Miyazawa et al., 1998). According to Dias et al. (1996), when the bio-solid dose is increased, there is a linear growth in $\mathrm{Ni}$ availability in the soil.

The Ni content found in the dry matter resulted from the use of a biosolid compost in this experiment was $63 \mathrm{mg} \cdot \mathrm{kg}^{-1}$, which is much lower than the 200 mg. $\mathrm{kg}^{-1}$ DM recommended by Switzerland and Germany, and by the $300 \mathrm{mg} \cdot \mathrm{kg}^{-1}$ DM recommended by the European Economic Community for its incorporation to the soil. However, the Ni content was higher than the 30 mg. $\mathrm{kg}^{-1}$ DM recommended by Denmark (Fernandes et al., 1993).

According to international criteria, the Ni content in soils varies from 0.7 to $269 \mathrm{mg} \cdot \mathrm{kg}^{-1}$ (Souza et al., 1996). The Ni critical level is established at 100 mg.kg ${ }^{-1}$ (Kabata-Pendias and Pendias, 1984).

\section{Lead}

Higher contents of $\mathrm{Pb}$ were observed in the root (3.38 to $18.85 \mathrm{mg} \cdot \mathrm{kg}^{-1} \mathrm{DM}$ ). They were lower in the stem (1.94 to 4.71 mg. $\left.\mathrm{kg}^{-1} \mathrm{DM}\right)$ and intermediate in the leaves $\left(6.19\right.$ to $9.10 \mathrm{mg} \cdot \mathrm{kg}^{-1}$ $\mathrm{DM})$. The lowest level of $\mathrm{Pb}$ content was obtained from coffee seedlings grown on pure $\mathrm{RH}$, which differed significantly from the root content grown on the $\mathrm{RH}$ and $\mathrm{BC}$ mixture or on pure $\mathrm{BC}$. As for the stem and leaves, no significant differences in content were found among the treatments.

There is usually a higher accumulation of $\mathrm{Pb}$ in the root than in the shoot height (Chu and Wong, 1987) in Brassica chinensis and Lycopersicum esculentum, as well as in wheat (Arteaga, 1996). However, $\mathrm{Pb}$ may accumulate more in the shoot height than in the root in carrots (Chu and Wong, 1987).

The use of biosolids from Treatment Stations in Paraná in bean plant plantations resulted in $\mathrm{Pb}$ contents similar to those of the witness (Miyazawa et al., 1998). On the other hand, there is a linear growth in the $\mathrm{Pb}$ availability when the bio-solid dose is increased (Dias et al. 1996).

$\mathrm{Pb}$ content in biosolid dry matter in this experiment $\left(198 \mathrm{mg} \cdot \mathrm{kg}^{-1}\right)$ is lower than the 400 mg. $\mathrm{kg}^{-1}$ DM recommended by Denmark and the $750 \mathrm{mg} \cdot \mathrm{kg}^{-1} \mathrm{DM}$ recommended by the European Economic Community for the incorporation of the material to the soil (Fernandes et al., 1993).

$\mathrm{Pb}$ concentration in biosolids varies from 29 to 3,600 mg. $\mathrm{kg}^{-1} \mathrm{DM}$, and these variations depend most probably on the economical activities of the sampled regions (Miyazawa et al., 1998).

According to international criteria, the $\mathrm{Pb}$ content in soils varies from 0.5 to $135 \mathrm{mg} \cdot \mathrm{kg}^{-1}$ (Souza et al., 1996) and $\mathrm{Pb}$ critical levels are between 100 and 400 mg.kg ${ }^{-1}$ (Kabata-Pendias and Pendias, 1984). Taking into consideration this critical level, it can be said that all soils without anthropic actions have $\mathrm{Pb}$ contents lower than the critical levels.

\section{Manganese}

The highest $\mathrm{Mn}$ content levels were observed in coffee plant leaves (113.07 to 477.76 mg. $\mathrm{kg}^{-1}$ $\mathrm{DM}$ ), and the lowest in the stems (56.35 to 132.74 mg. $\left.\mathrm{kg}^{-1} \mathrm{DM}\right)$. The roots showed intermediate content levels (76.39 to $179.01 \mathrm{mg} . \mathrm{kg}^{-1} \mathrm{DM}$ ).

Adequate contents for coffee plant leaves vary from 80 to $100 \mathrm{mg} \cdot \mathrm{kg}^{-1} \mathrm{DM}$ (Malavolta et al., 1997). So, according to this standard, seedlings presented higher leaf contents than the adequate for all substrates.

While working with a standard substrate for coffee, Guimarães (1994) observed that $\mathrm{Mn}$ content in leaves and stems decreased according to the age of the coffee plant, varying from 60.1 mg. $\mathrm{kg}^{-1} \mathrm{DM}$ (in seedlings with one leaf pair) to $22.7 \mathrm{mg} \cdot \mathrm{kg}^{-1} \mathrm{DM}$ (in seedlings with eight leaf pairs), and from $18.6 \mathrm{mg} \cdot \mathrm{kg}^{-1} \mathrm{DM}$ to $13.4 \mathrm{mg} \cdot \mathrm{kg}^{-1}$ $\mathrm{DM}$ in the plant stem, with one and eight leaf pairs respectively. 
Mn contents in coffee plant roots are close to 30 mg. $\mathrm{kg}^{-1} \mathrm{DM}$ in seedlings with one to eight pairs of leaves. Depending on the species, Mn may accumulate more in the leaves, as in carrots, or in the roots, as in Brassica chinensis and Lycopersicum esculentum (Chu and Wong, 1987), than in the shoot height. In this study, notwithstanding the part of the plant analyzed, Mn content was higher and significantly different every time pure RH was utilized during leaf formation. The use of $\mathrm{BC}$ mixed with $\mathrm{RH}$ reduced $\mathrm{Mn}$ content in the leaves to an adequate level. These results are due to the higher Mn content found in the analysis of carbonized rice hull. While studying bean plant cultures, Miyazawa et al. (1998) observed that higher Mn concentration in the substrate increased the content of this metal in the plant shoot height tissues.

Mn contents found in the biosolid compost and carbonized rice hulls used in this experiment was $503 \mathrm{mg} \cdot \mathrm{kg}^{-1} \mathrm{DM}$ and $705 \mathrm{mg} \cdot \mathrm{kg}^{-1} \mathrm{DM}$, respectively. Switzerland recommends $\mathrm{Mn}$ content of $500 \mathrm{mg} \cdot \mathrm{kg}^{-1} \mathrm{DM}$ at the most for the incorporation of the material to the soil (Fernandes et al., 1993). According to Miyazawa et al. (1998), Mn contents higher than $300 \mathrm{mg} \cdot \mathrm{kg}^{-1} \mathrm{DM}$ in the biosolid caused toxicity symptoms in the bean plants.

\section{Copper}

On average, higher accumulation of $\mathrm{Cu}$ (9.57 to $\left.59.19 \mathrm{mg} \cdot \mathrm{kg}^{-1} \mathrm{DM}\right)$ was found in coffee plant roots. Leaves and stems presented similar content levels, varying from 6.07 to $11.07 \mathrm{mg} \cdot \mathrm{kg}^{-1} \mathrm{DM}$. Adequate content levels for coffee plant leaves vary from 11 to $14 \mathrm{mg} \cdot \mathrm{kg}^{-1} \mathrm{DM}$ (Malavolta et al., 1997). These are higher than the contents observed in seedlings, in all substrates. Pure or mixed BC produced a significant increase in $\mathrm{Cu}$ content in the roots. The highest $\mathrm{Cu}$ content was found in the roots of seedlings grown on pure BC and on $75 \%$ of $\mathrm{BC}$ mixed with $25 \%$ of $\mathrm{RH}$ and in the stems of seedlings grown on $50 \%$ of $\mathrm{BC}+50 \%$ of $\mathrm{RH}, 75 \%$ of $\mathrm{BC}+25 \%$ of $\mathrm{RH}$ and $100 \%$ of BC. These results differ significantly from those found in seedlings grown on pure RH. There were no content differences in the leaves. However, whenever pure $\mathrm{BC}$ was used, the $\mathrm{Cu}$ content got closer to the minimum adequate level for leaves.

While working with a standard substrate for coffee, Guimarães (1994) determined that $\mathrm{Cu}$ content in roots, stems and leaves increases according to the age of the plants. In the root, it changes from $14.9 \mathrm{mg} \cdot \mathrm{kg}^{-1} \mathrm{DM}$ to $57.1 \mathrm{mg} \cdot \mathrm{kg}^{-1}$ $\mathrm{DM}$; in the stem, from $13.1 \mathrm{mg} \cdot \mathrm{kg}^{-1} \mathrm{DM}$ to 22.2 $\mathrm{mg} . \mathrm{kg}^{-1} \mathrm{DM}$, and in the leaves from $6.5 \mathrm{mg} \cdot \mathrm{kg}^{-1}$ $\mathrm{DM}$ to $11.8 \mathrm{mg} \cdot \mathrm{kg}^{-1} \mathrm{DM}$, respectively for coffee plant seedlings with one to eight pairs of leaves.

Depending on the species, the $\mathrm{Cu}$ accumulates more in the leaves, as in Brassica chinensis and Lycopersicum esculentum (Chu and Wong, 1987), and in wheat (Arteaga, 1996), than in the shoot height. The use of biosolids from Treatment Stations in Paraná in bean plant plantations resulted in $\mathrm{Cu}$ contents similar to those of the witness (Miyazawa et al., 1998).

The $\mathrm{Cu}$ contents found in biosolid composts and carbonized rice hulls used in this experiment were $517 \mathrm{mg} \cdot \mathrm{kg}^{-1} \mathrm{DM}$ and $53 \mathrm{mg} \cdot \mathrm{kg}^{-1} \mathrm{DM}$, respectively. Switzerland and the European Economic Community accepts maximum contents of 1,000 mg. $\mathrm{kg}^{-1}$ DM. In Sweden, contents up to 3,000 mg. $\mathrm{kg}^{-1} \mathrm{DM}$ are accepted (Fernandes et al., 1993).

\section{Zinc}

Coffee plant roots showed the highest accumulation of $\mathrm{Zn}$ (107.82 to $\left.1474.65 \mathrm{mg} \cdot \mathrm{kg}^{-1} \mathrm{DM}\right)$. Leaves accumulated the least (12.83 to $22.05 \mathrm{mg} \cdot \mathrm{kg}^{-1} \mathrm{DM}$ ), and the stem showed intermediate content levels (18.77 to $\left.99.47 \mathrm{mg} \cdot \mathrm{kg}^{-1} \mathrm{DM}\right)$. Adequate $\mathrm{Zn}$ content levels for coffee plant leaves are from 15 to 20 mg. $\mathrm{kg}^{-1}$ DM (Malavolta et al., 1997). When carbonized rice hulls were used as substrate, $\mathrm{Zn}$ leaf contents were lower than the standard, but this did not happen when the bio-solid compost was used. Leaf contents from seedlings cultivated in substrate mixtures were within the standards. Coffee trees demand a high level of $\mathrm{Zn}$ during their nutrition process. BC has become an important nutritious source for coffee trees.

Depending on the species, $\mathrm{Zn}$ accumulates more in the leaves, as in carrots, or in the roots, as in Brassica chinensis and Lycopersicum esculentum (Chu and Wong, 1987), than in the shoot height. Arteaga (1996) did not notice any significant differences between the accumulated contents in the root and in the shoot height in wheat. Coffee seedlings grown on pure $\mathrm{BC}$ or mixed with $\mathrm{RH}$ presented significantly higher $\mathrm{Zn}$ content in the roots and stems than in those grown on pure RH. There was no difference in leaf content among the treatments.

$\mathrm{Zn}$ contents found in the biosolid compost and carbonized rice hulls were $1,560 \mathrm{mg} \cdot \mathrm{kg}^{-1} \mathrm{DM}$ and 86 mg. $\mathrm{kg}^{-1}$ DM, respectively (Table 2). The European Economic Community accepts maximum 
contents of 2,500 mg. $\mathrm{kg}^{-1}$ DM. In Sweden, the values can reach up to $10,000 \mathrm{mg} \cdot \mathrm{kg}^{-1} \mathrm{DM}$, so that sewage sludge from treatment stations can be incorporated to the soil (Fernandes et al., 1993).

According to international standards, the $\mathrm{Zn}$ content in soils varies from 1.5 to $264 \mathrm{mg} \cdot \mathrm{kg}^{-1}$ (Souza et al., 1996) The $\mathrm{Zn}$ critical levels are between 70 to $400 \mathrm{mg} \cdot \mathrm{kg}^{-1}$ (Kabata-Pendias and Pendias, 1984).

In general, the $50 \%$ of $\mathrm{RH}+50 \%$ of $\mathrm{BC}$ treatment is the best for the nutrition of coffee trees, reducing the excessive $\mathrm{Mn}$ to an adequate level and the $\mathrm{Zn}$ from an adequate low to an adequate average level.

\section{ACKNOWLEDGEMENTS}

To doctor Fernando Fernandes and to the Paraná Sanitation Company - SANEPAR.

\section{RESUMO}

Estudou-se o efeito do biossólido compostado (BC), da casca de arroz carbonizada (CA) e das misturas na produção de mudas de Coffea arabica L. cv Catuaí Vermelho, IAC-99, em tubetes. O experimento foi instalado em viveiro para avaliar os teores de $\mathrm{Co}, \mathrm{Ni}, \mathrm{Cr}, \mathrm{Pb}, \mathrm{Cd}, \mathrm{Cu}, \mathrm{Mn}$ e $\mathrm{Zn}$ na raiz, caule e folha. $\mathrm{O}$ delineamento experimental utilizado foi o inteiramente casualizado, com cinco tratamentos e quatro repetições. Os maiores teores de $\mathrm{Cr}, \mathrm{Co}, \mathrm{Ni}, \mathrm{Pb}, \mathrm{Cu}$ e $\mathrm{Zn}$ foram encontrados na raiz e o maior de $\mathrm{Mn}$ na folha. $\mathrm{O}$ teor de $\mathrm{Zn}$ na folha foi de adequado médio a adequado alto em plantas desenvolvidas em $\mathrm{BC}$ ou em suas misturas. Em plantas desenvolvidas em CA o teor de Mn foi superior cerca de quatro vezes a concentração considerada adequada. Os teores de $\mathrm{Ni}, \mathrm{Co}, \mathrm{Cr}, \mathrm{Pb}$ e $\mathrm{Cu}$ verificados nas folhas podem ser considerados normais segundo padrões internacionais. $\mathrm{O}$ tratamento melhor para a nutrição do cafeeiro foi $50 \%$ de CA $+50 \%$ de BC.

\section{REFERENCES}

Amaral, R. D.; Barros, N. F.; Costa, M. L. and Fontes, M.P.F. (1996), Efeito de um resíduo da indústria de zinco sobre a química de amostras de solo e plantas de milho. Rev. Bras. Ciência do Solo, 20, 433-440.
Andreoli, C. V. and Pegorini, E. S. (1998), Gestão de biossólidos: situações e perspectivas. In: Seminário sobre Gerenciamento de Biossólido do Mercosul, 1-4 Dec. Curitiba : SANEPAR/ABES.

Arteaga, D. H. (1996), Dinâmica de cádmio, chumbo, cobre, níquel e zinco no sistema solo-planta. Dissertação (Mestrado), Universidade Federal de Viçosa, Brasil.

Berton, R. S.; Camargo, O. A. and Valadares, J. M. A. S. (1989), Absorção de nutrientes pelo milho em resposta à adição de lodo de esgoto a cinco solos paulistas. Rev. Bras. Ciência do Solo, 13, 187-192.

Bidwell, A. M. and Dowdy, R. H. (1987), Cadmium and zinc availability to corn following termination of sewage sludge applications. J. Environmental Quality, 16, 438-442.

Biscaia, R. C. M. and Miranda, G. M. (1996), Uso do lodo de esgoto calado na produção de milho. Sanare, 5 : (5), 86-89.

Chu, L. M and Wong, M. H. (1987), Heavy metal contents of vegetable crops treated with refuse compost and sewage sludge. Plant and Soil, 103, 191-197.

Dias, F. L. F; Bellingieri, P. A. and Seki, L. T. (1996), Efeito da aplicação de calcário, de lodo de esgoto e de vinhaça sobre as propriedades químicas de um solo cultivado com sorgo granífero. Cultura Agronômica, 5 : (1), 51-62.

Euclides, R. F. (1983), Sistema para análises estatísticas e genéticas: manual provisório. Viçosa : CPD/UFV. 74 pp.

Fernandes, F.; Coelho, L. O.; Nunes, C. W. and Silva, S. M. C. P. (1996), da. Aperfeiçoamento da tecnologia de compostagem e controle de patógenos. Sanare, 5 : (5), 36-45.

Fernandes, F.; Pierro, A. C. and Yamamoto, R. Y. (1993) Produção de fertilizante orgânico por compostagem do lodo gerado por estações de tratamento de esgotos. Pesquisa Agropecuária Brasileira, 28 : (5), 567-574.

Guimarães, R. J. (1994), Análise do crescimento e da quantificação de nutrientes em mudas de cafeeiro (Coffea arabica L.), durante seus estádios de desenvolvimento em substrato padrão. Dissertação (Mestrado), Escola Superior de Agricultura de Lavras, Brasil.

Jorge, J. A.; Camargo, O A. and Valadares, J. M. A. S. (1991), Condições físicas de um Latatossolo Vermelho-Escuro quatro anos após aplicação de lodo de esgoto e calcário. Rev. Bras. Ciência do Solo, 15, 237-240.

Kabata-Pendias, A. and Pendias, H. (1984), Trace elements in soils and plants. 3. ed. Boca Raton : CRC. 315 pp.

Lara, A. I. (1999), Reciclagem de biossólidos Transformando problemas em soluções. Curitiba : Sanepar. 300 pp. 
Malavolta, E.; Vitti, G. C. and Oliveira, S. A. (1997). Avaliação do estado nutricional das plantas princípios e aplicação. 2. ed. Piracicaba : Potafós. 319 pp.

Miyazawa, M.; Oliveira, E. L.; Parra, M. S. and Yamashita, M. (1998), Absorção de metais pesados do lodo de esgoto pelo feijoeiro (Phaseolus vulgaris L.). Brazilian Archives of Biology and Technology, 41 : (1), 115-127.

Ortega, E.; Nogales, R. and Delgado, M. (1981), Modificación en la porosidad de un suelo por la adición de un compost de basura urbana. Analogica, Edafologica y Agro-biologica, 15, 1735-1747.

Pagliai, M.; Guidi, G.; La Marca, M.; Giachetti, M. and Lucamante, G. (1981), Effects of sewage sludge and composts on soil porosity and aggregation. Journal of Environmental Quality, 10, 556-561.

Soccol, V. T.; Paulino, R. C.; Castro, E. A. and Tracz, J. (1997), Eficácia dos diferentes processos de tratamento do lodo na redução da viabilidade de ovos de helmintos. Sanare, $8:(8), 1-72$.

Souza, F. X. (1993), Casca de arroz carbonizada: um substrato para a propagação de plantas. Lavoura Arrozeira, 46 : (406), 11.

Souza, M. L. P.; Andreoli, C. V.; Amaral, M. B. and Domaszak, S. C. (1996), Levantamento preliminar dos teores de metais pesados em alguns solos do Paraná. Sanare, 5 : (5), 68-75.

Tiller, K. G. (1989), Heavy metals in soils and their environmental significance. Advances in Soil Sciences, 9, 113-142.

Tsadilas, C. D.; Matsi, T.; Barbayiannis, N. and Dimoyiannis, D. (1995), Influence of sewage sludge application on soil properties and on the distribution and availability of heavy metal fractions. Communications in Soil Science and Plant Analysis, 26 : (15-16), 2603-2619.

Wallace, A. and Wallace, G. A. (1994), A possible flaw in EPA's 1993 new sludge rule due to heavy metal interactions. Communications in Soil Science and Plant Analysis, 25, 129-135. 